\title{
CULTURE AND COSMOS
}

A Journal of the History of Astrology and Cultural Astronomy

\section{Vol. 5 no 1, Spring/Summer 2001 \\ Published by Culture and Cosmos and the Sophia Centre Press,}

in partnership with the University of Wales Trinity Saint David, in association with the Sophia Centre for the Study of Cosmology in Culture,

University of Wales Trinity Saint David, Faculty of Humanities and the Performing Arts Lampeter, Ceredigion, Wales, SA48 7ED, UK.

\section{www.cultureandcosmos.org}

Cite this paper as: Campion, Nicholas, 'Editorial', Culture and Cosmos, Vol. 5 no 1, Spring/Summer 2001, pp. 1-2.

\section{British Library Cataloguing in Publication Data}

A catalogue card for this book is available from the British Library

All rights reserved. No part of this book may be reproduced or utilized in any form or by any means, electronic or mechanical, including photocopying, recording or by any information storage and retrieval system, without permission in writing from the Publishers.

\section{ISSN 1368-6534}

Printed in Great Britain by Lightning Source

Copyright (C) 2018 Culture and Cosmos

All rights reserved 


\section{CULTURE AND COSMOS}

Vol. 5 No. 1 Spring/Summer 2001 ISSN 1368-6534

\section{Editorial}

The following announcement has been issued by Professor Ray White, one of the founders of the innovatory series of conferences on The Inspiration of Astronomical Phenomena:

The Fourth International Conference on The Inspiration of Astronomical Phenomena (INSAP IV) will be held at Magdalen College, Oxford on August 3rd - 9th 2003. This meeting will explore humanity's fascination with the sky by day and by night, which has been a strong and often dominant element in human life and culture. The conference will provide a meeting place for artists and scholars from a variety of disciplines (including archaeology and anthropology, art and art history, classics, history and prehistory, the physical and social sciences, mythology and folklore, philosophy, and religion) to present and discuss their studies of the influences that astronomical phenomena have had on humanity.

The first three meetings (Castel Gandolfo, 1994; Malta, 1999; Palermo, 2001) successfully brought together for the first time people from just such a range of disciplines to address topics of common interest. Papers from the first meeting were published in Vistas in Astronomy (1995) and in Leonardo (1996), those from the second will appear shortly in book form, and those from the third will appear in 2002 in a special issue of Memorie della Società Astronomica Italiana. These papers (described on our Website under each INSAP Conference) give an idea of the range of subjects presented at these meetings.

A similar publication is planned for the fourth meeting, which will be held in Magdalen College, Oxford (UK), starting Sunday August 3 , 2003. Attendance will be by invitation from among those applying. All presentations and discussions will be in English. This Conference is sponsored by the Vatican Observatory and the 
Steward Observatory. Further information on INSAP IV and on the earlier conferences, and an application form for the upcoming meeting, can be found on our Website (http://ethel.as.arizona.edu/ white/insap) or obtained from the undersigned.

Dr. Valerie Shrimplin, University of Luton: Co-Chair, Local Organizing Committee, valerie.shrimplin@luton.ac.uk, Mr. Nick Campion, Bath Spa University College: Co-Chair, Local Organizing Committee, ncampion@ caol.demon.co.uk, Professor David W. Pankenier, Lehigh University: Coordinating Member, International Executive Committee david.pankenier@lehigh.edu.

Nicholas Campion Study of Religions Department Bath Spa University College 